\title{
The Attachment of Adolescent with Working Mother
}

\author{
Enung Huripah \\ Meilani Dewi Setiamanah \\ Rohman Rauf Alfansuri \\ Bandung College of Social Welfare \& Social Worker
}

\begin{abstract}
Adolescence is often called the preparation period for becoming adult where individually they act and behave and grow into adulthood. The successful development process of adolescent to adulthood depends on care and guidance from people in their family or parents especially mother. The research focus was aimed to analyse the attachment of adolescent with working mother. The purpose of the research was to analyse characteristic, attachment of adolescent with working mother, the relationship and meeting intensity between adolescent and working mother. This research used qualitative approach. Data resource consisted four working mothers and four adolescents who have working mother. Data collection technique used in-depth interview, passive participation observation and documentation study. The analysis stage covering data reduction, data presentation and conclusion. The result showed that the attachment of adolescent with working mother have differences between one family and another. Factors that may affect attachment intensity differences between adolescent with working mother covering; history of child care using caregiver or housemaid; awareness and understanding of adolescent and working mother respective activities; and alternative effort which is conducted by adolescent and working mother to overcome that obstruct communication.
\end{abstract}

Keywords : Attachment, Adolescent, Working Mother.

\section{Introduction}

Children have a very important position in the survival of a family, community, nation, and country. Children is a bud that will grow and develop into part of the next generation of struggle in order to achieve the ideals of a nation. A child is a person who is not yet 21 years old, including a child who is still in the womb. The child is a member of the family born from the fruit of love father and mother. A child will not be far from parenting, especially his mother. For a child, the role of parents, especially mothers, has meaning and function that is very important for survival and in finding the meaning and purpose of life. Therefore, the role of the mother in the formation of the child's personality is very important in the child's development before adulthood (Lestari, 2012). 
Child development is divided into five periods that include the prenatal period, neonates period, infancy, childhood, and puberty (Hurlock, 1980). The period of pre-birth that starts from the moment of conception until birth. In this period there is a very rapid physiological development of whole body growth as a whole. The period of neonates is a newborn period. This period starts from 0 to 14 days. In this period the infant adaptes to an entirely new environment for the baby that is the environment outside the womb. Infant period is infant age 2 weeks to 2 years. At this time, babies learn to control their own muscles until the baby has the desire to be independent. Children's period consists of two parts: the early childhood and childhood. Early childhood is a child aged 2 to 6 years, this period is also called the pre-school period of child social adjustment. The end of the childhood is the age of 6 to 13 years, or referred to as school age. Puberty is a child aged 11 to 16 years. This period includes overlapping periods because it is a 2 year period of late childhood and 2 years of early adolescence. Physically the child's body in this period turns into an adult body (Hurlock, 1980). Based on age, development and growth of children into three age groups ie age $0-7$ years is the stage of childhood; $7-14$ years of age are childhood, study period or elementary school period; and the age of 14 - 21 years is adolescence or puberty, the transition from childhood to adulthood (Aristotle in Hurlock, 1980).

Child ages 12 to 21 years is a child's development period is very vulnerable and decisive for the development of adult life. This period is often referred to as adolescence. Psychologically adolescence is the age of the individual integrated with the adult society, the age at which the child no longer feels below the level of the elderly but at the same level, at least in the rights issue (Piaget in Hurlock, 1980). Therefore, adolescence is often called the period of preparation for becoming an adult where individual adolescents will act and behave independently and grow into adults (Hurlock, 1980).

In adolescence there are several phases that have different characteristics and problems and needs (Monk, 2006). Phase divisions include; early teens (ages 12 to 15), middle teenagers (ages 15 to 18), late adolescents (ages 18 to 21 years) and among them also a phase of puberty which is a very short phase and sometimes a separate problem for adolescent to deal with it (Monk, 2006). Tasks of adolescent development include; achieve new and more mature relationships with peers of both men and women; achieve the social role of men, and women; accept his physical state and use his body effectively; expect and achieve responsible social behavior; achieve emotional independence from parents and other adults; preparing for an economic career; preparing for marriage and family; and acquire value devices and ethical systems as guidelines for behaving-developing ideologies (Havighurst in Hurlock, 1980).

In every phase of adolescence has the characteristics and problems in the development of life (Monks, 2006). Various characteristics and problems have an influence on the development of his life as an adolescent stepped on adulthood. In early 
adolescence (12-15 years), adolescents still feel confused and begin to adapt to the changes that occur to him and the impulse that accompanies these changes Monks (2006). They begin to develop new thoughts, quickly attracted to the opposite sex and are easily aroused erotic. This excessive sensitivity is coupled with reduced control of emotions and causes adolescents to be difficult to understand and understand by adults.

In middle adolescence (15-18 years), adolescents desperately need friends (Monks, 2006). There is a narcissistic tendency to love oneself, preferring friends who share the same characteristics as themselves. At this stage adolescents are in a state of confusion because they still hesitate to choose the same, sensitive or care, crowded or own, optimistic or pessimistic, and so forth. In late adolescence (18-21 years) is a period approaching maturity that is marked by the achievement of an increasingly steady interest in intellectual functions; the ego seeks opportunities to unite with others and gain new experiences; the formation of sexual identity that will not change again; egocentrism (over-focusing on self) is replaced by a balance of self-interest with others; and a growing wall of separation between oneself and the general public (Monks, 2006).

Based on the characteristics of adolescent above, adolescence is an important period, the transition period, the change period, the problematic period, and also the search period of identity which at this age creates fear in adolescent self (Monks, 2006). Adolescence is a period of transition and a period of change into adulthood in the development of life (Monk, 2006). These changes include physical change, emotional change, and social change. Physical changes related to aspects of anotomy and physiology aspects, in the adolescent pituitary gland gland becomes ripe and release some hormones, such as gonotrophic hormone that serves to accelerate the maturation of eggs and sperm, and affect the production of corticortop hormone function affect the suprenalis gland, testosterone, oestrogen, and suprenalis which affects the growth of children resulting in accelerated growth (Monks, 2006).

On the other hand, emotional changes occur in adolescent emotional patterns similar to the emotional patterns in childhood (Hurlock, 1980). Emotional patterns are angry, fearful, jealous, curious, jealous, joyful, sad and affectionate. The difference lies in the stimulation that evokes emotions and control in expressing emotions (Hurlock, 1980). Teenagers generally have an emotional state of unstable extreme experiences and always feel the pressure. If at the end of adolescence is able to refrain from expressing emotions extreme and able to express emotions appropriately in accordance with the situation and conditions of the environment and in a way that is acceptable to society, in other words adolescents who reach emotional maturity will provide a stable emotional reaction (Hurlock, 1980).

Physical and emotional changes in adolescence also result in adolescent social change and development (Monks, 2006). There are two forms of adolescent social development that is, separating themselves from parents and toward the peer group. Adolecents are trying to break away from parental authority with the intent of finding identity (Monks, 2006). Adolescents are mostly stay out and gathering with their peers 
by forming groups and expressing all their potential. This condition makes adolescents very vulnerable to the influence of friends in terms of interest, attitude and appearance behavior. The most notable change is the heterosexual relationship. Adolescents will show a radical change from not liking the opposite sex to prefer. Teens want to be accepted, cared for and loved by the opposite sex and the group (Monks, 2006).

The success of the development process of adolescent life towards adulthood depends on the attention and guidance of the nearest person in the family environment or father and mother as his parents, especially mothers (Nurul in Lestari, 2012). Mother is a woman who has been pregnant for nine months and has given birth to a child and caring with affection. Mother is a figure of understanding, understand the various things that exist in the child in terms of raising, guiding, and supervising the development of his son to a better direction. The role of mothers in guiding and supervising their children has a significant effect on the success of the child's life during adulthood (Nurul in Lestari, 2012).

The important role of housewives in the family includes as a manager, as a teacher, as a chef, as a nurse, as an accountant, as an interior designer, and as a doctor (Sharif Baqhir, 2006). As a manager, a housewife is able to integrate various character, various state / condition of her family member into one household purpose. Mother plays the role of regulator of the continuity of the wheels of his household everyday (Sharif Baqhir, 2006). As a teacher, a mother role educates her children, teaches something new, trains, guides, directs and provides good judgment in the form of reward and punishment that educate. Mother is the most important teacher in the formation of the child's personality, as well as the means to meet the needs of his children with various noble traits (Sharif Baqhir, 2006). As a chef, a mother must be good at creating food menus that are acceptable to all family members, whether the food menu for breakfast, lunch, or dinner. Housewives also play a role in maintaining family health (Sharif Baqhir, 2006). As a nurse, a mother takes care of her children as a baby until adolescence. A mother watches the intake of nutritional food with affection and sincere attention (Sharif Baqhir, 2006). As an accountant, a mother plays a role in managing the family income and expenditure budget as well as possible (Sharif Baqhir, 2006). As an interior design, a mother plays a role in creating / organizing a variety of household appliances to create a pleasant atmosphere for family members' activities at home (Sharif Baqhir, 2006). The role of mother as a doctor is to maintain the health of his children and seek healing of various diseases affecting her children (Sharif Baqhir, 2006).

Children in adolescence are entitled to welfare, care, upbringing and guidance based on compassion to grow and develop properly (Hurlock, 1980; Monk, 2006; Ainsworth in Dariyo, 2011; Nurul in Lestari, 2012). The demand for the fulfillment of the welfare of children in adolescence can not be separated from the relationship of the parent's role to the child that is his responsibility, either through the provision of affection in maintaining the development of his life as well as the sense of security, and the tranquility of the child with his parents (Ainsworth in Dariyo, 2011). A 
harmonious, attached relationship and a mother's sensitivity to respond appropriately to adolescent problems will determine adolescent success in adulthood (Hurlock, 1980; Monk, 2006; Ainsworth in Dariyo, 2011; Nurul in Lestari, 2012). Therefore, a harmonious and adherent relationship between mother and adolescent is an emotional and cognitive source for adolescents in dealing with their developmental life (Ainsworth in Dariyo, 2011).

Stickiness (attachment) of mothers with children is an emotional attachment reciprocal between adolescent with parents caused by the development of the quality of the previous relationship where a child's early years while still in the care of parent (Ainsworth in Ervika, 2005). However, not all relationships that are emotional and affective can be called attachment. The affective trait that shows attachment is that the relationship lasts long enough, bonding remains even though the sticky figure is not visible within the reach of the child's eyes (Ainsworth in Ervika, 2005).

Based on the quality of adolescent attachment with the mother, adolescent will develop a mental construction or internal working models of the self and others that will be an assessment of the environmental acceptability mechanism (Bowlby in Dariyo, 2011). In the implementation, there is often a failure and disruption of adherence between adolescents with their mothers. This disruption occurs because adolescents fail to form a secure attachment with a sticky figure. This situation will make teenagers have problems in social relationships. This attachment status is associated with adolescent adolescent attitudes to primary caretakers and adolescent development in the future (Bowlby in Dariyo, 2011).

Attachment refers to the bond between two individuals or more, the nature of which is discriminatory and specific psychological relationships, and binds a person with others in a certain span of time and space (Kuper \& Kuper in Desmita, 2007). Attachment is a reciprocal emotional attachment between a child and a parent caused by the development of the quality of the previous relationship (Papalia in Dariyo (2011). Parents who meet the basic needs of decent will create feelings of security, comfort and quiet for children (Hurlock, 1980, Monk, 2006) .The attachment is an emotional bond as a form of behavior shown by the individual in achieving or maintaining closeness with other individuals identified as someone who has better ability to face life (Bowlby in Desmita (2007) .

Children are psychologically bound to their parents (Hurlock, 1980; Monk, 2006; Ainsworth in Dariyo, 2011; Nurul in Lestari, 2012). The child first experiences attachment to the mother and shortly thereafter with a significant other than the mother (significant other), and believes that attachment to the child is the primary basis for the formation of the child's social life in the future (Bowlby in Desmita, 2007). Referring to that opinion, the attachment is the form or structure of the emotional bond as a form of behavior shown by the individual in achieving or maintaining closeness with other individuals who are identified as someone who has better ability to face life. 
There are three attachment patterns, namely the secure attachment pattern, the anxious resistant attachment, and the anxious avoidance attachment (Bowlby in Dariyo, 2011). The secure attachment pattern is a pattern formed by the parent's interaction with the child, where the child feels confident in the parent as an accompanying, sensitive, responsive, loving and affectionate figure as they seek refuge and comfort, and always help or help in face a frightening and threatening situation. Children who have this pattern believe in the responsiveness and willingness of parents for themselves (Bowlby in Dariyo, 2011).

The pattern of anxious resistant attachment is a pattern formed from the parent's interaction with the child, where the child feels uncertain that his or her parents are always there and responsive or quick to help and come to him when the child needs them. As a result, the child is easily anxious to separate, dependent, demanding attention, and anxious when exploring in the environment. In this pattern, the child experiences uncertainty as a result of parents who are not always helpful at every opportunity and also separation (Bowlby in Dariyo, 2011). On the other hand, the pattern of anxious avoidance attachment is a pattern that is formed from parents with children, where children do not have confidence because when looking for affection, children are not responded or even rejected. In this pattern, conflicts are more hidden as a result of parental behavior that constantly rejects them as the child approaches to seek comfort or protection (Bowlby in Dariyo, 2011).

From the individuals side involved in the process of attachment, there are four attachment styles, namely; (1) secure attachment style; (2) fearfull-avoidant attachment style; (3) pre-occupied attachment style; and (4) dismissing attachment style (Bowlby in Dariyo, 2011). In secure attachment style, individuals are described as individuals who have high self-esteem and interpersonal trust, have a positive outlook about themselves and others and are able to create interpersonal relationships based on mutual trust (Bowlby in Dariyo, 2011). In the fearfull-avoidant attachment style, individuals have negative views about themselves and others, they avoid rejection by avoiding close relationships with others (Bowlby in Dariyo, 2011). In pre-occupied attachment style, individuals have negative views about themselves but still expect others to accept and love themselves, so that individuals of this type seek to make connections with others but they are afraid to be rejected (Bowlby in Dariyo, 2011). In dismissing attachment style, individuals have a positive character in self-esteem, feel valuable and self-reliant, and feel worthy to get or make a close relationship with others, but sometimes they reject a genuine relationship because they expect other people who are worse than them, this pattern is classified on the negative side (Bowlby in Dariyo, 2011).

Differences in attachment style will make a big difference in viewing himself and others (Myers in Desmita (2007) .The people categorized as having secure attachment will have higher self-efficacy, more confidence in social situations and more assertiveness. have positive beliefs about the social world, view others as common people.Individuals who include anxiety show less feelings of feeling, confidence in 
low social situations, and less assertive (Myers in Desmita (2007). Individuals including avoidance tend to see themselves as positively self-assertive and assertive even though they are less confident in social situation and less oriented in interpersonal relations (Myers in Desmita (2007).

Persons with a secure attachment style represent characteristic of a friendly and confident individual. Individuals with attachment style avoid having character of a skeptical, suspicious, easy-to-change and hard-to-open individual. They are uncomfortable in intimacy, unable to express themselves, less warm, and less open. Individuals with anxious personality traits show an insolent, insecure, unworthy, volatile, non-assertive, and daring person (Seifert \& Hoffnung in Desmita, 2007).

Attachement is formed from the underlying aspects. Aspects of attachment include the sensitivity of figures, and the responsiveness of figures (Papalia in Dariyo, 2011). The sensitivity of figures can be how big the sensitivity of the figure to the needs of the individual or the extent to which the sticky figure can know the needs of the individual. On the other hand, responsiveness is how sticky figures respond to individual needs. The main aspect of the formation and development of attachment is the acceptance of the adhesive figure, the sensitivity or sensitivity of the inherent figure to the individual needs and the sensitivity of both the both fixed and individual figures in response to the stimuli given to strengthen the attachment between the two. In terms of function, attachment consists of attachments, affective relationships, the frequency / intensity of long-lasting encounters, reciprocal interactions, binding in an affinity, and is a very strong emotional bond (Bowlby 1958, Mary Ainsworth, 1979 in Desmita, 2007).

From the description that the main attachment aspect is the sensitivity or sensitivity of the attachment figure and the responsiveness or the way the figure closely responds to individual needs. Another component of Bowlby's (1958) theory is that attachment consists of three main components: the attachment, the relationship between the two, and the frequency / intensity of the relationship (Bowlby in Dariyo, 2011).

Attachment can have a positive effect on adolescent who get it, among others; confident; the ability to build a warm hubugan; loving others and caring for others; discipline; and good intellectual and psychological growth (Dariyo, 2011). Parents' attentions and affection are stable, fostering the belief that adolescents themselves are valuable to others (Dariyo, 2011). Guarantees of stable parental attention, make children learn to believe in others (Dariyo, 2011). On the other hand, the relationship that children get from parents, a lesson for children to later applied in life after adulthood. Warm attachment, a benchmark in forming relationships with friends and others. But a bad relationship, a traumatic experience for the child, thus preventing the ability to build a stable and harmonious relationship with others. Children who grow in a warm attachment relationship, will have a high sensitivity or sensitivity to the surrounding needs (Dariyo, 2011). He has a high level of concern and the need to help others in need of help. Stickiness helps parents to be able to more easily understand the child, so it is easier to give directions more proportionally, empathically, patiently and 
deeply. The child will also learn to develop self-awareness from the attitude of parents who respect the child to obey the rules with discipline because punishing behavior will hurt the child's self-esteem and not encourage self-awareness (Dariyo, 2011). The interwoven forms of attachment affect the physical, intellectual, and cognitive growth, as well as the development of individual psychology (Dariyo, 2011).

The benefits of attachment between individual adolescents with parents especially with someone who became a sticky figure among others; can generate a sense of selfreliance, the ability to build a warm relationship, love others and care for others, foster discipline, influence intellectual and psychological growth, foster better self-esteem and well-being in adolescents, and help teenagers to generate positive relationships with their adherent figures Dariyo, 2011).

Along with the current development and the era of globalization is more advanced, the mothers in Indonesia in general are given the same opportunities and roles with men in work (Nurul in Lestari, 2012). Not only as an increasingly advanced era, but the increasing economic needs that require a working mother to help the economy in the family. The phenomenon that occurs today is in addition to the fact that working mothers are increasingly able to express themselves in developing the role of mothers in the midst of family, and society, also driven by the economic needs of families in the household (Nurul in Lestari, 2012).

Basically a person works because there is something he wants to achieve, and one hopes that his work activities will lead to a more satisfying state than the previous situation (Magnis, 1998). Thus it can be said that in man there are needs that in time form the goals to be achieved and fulfilled. In order to achieve those goals, people are driven to perform an activity known as work (Magnis, 1998). But not all activities can be said to work. According to the work is a planned activity. Work requires special thinking and can not be run by animals. The work is carried out not only because it is pleasing, but because of a genuine willingness to attain a result which then stands alone or as an object, work, energy, etc. or as a service to society (Magnis, 1998).

Work is the use of mental and physical processes in achieving some productive goals (Brown in Anoraga, 1998). Work allows people to express themselves objectively to this world, so that he and others can see and understand his existence. From that opinion, what can be categorized as work is only the activities of people who are motivated on the economic needs alone, while those who engage in activities in social foundations or those who are members and active in social activities without getting any reward can not be regarded as work Brown in Anoraga, 1998).

There are several types of workers include; workaholic, workshy, and work tolerant (Brown in Anoraga, 1998). Workaholic is a person who is addicted to work, very tied to work and can not stop working. Workshy is a lazy person who does not want to do a job, and does something disgusting. The Tolerant guy is the person who works as little as possible to get maximum results and sees work as something that is unpopular but must be done (Brown in Anoraga, 1998). 
The research was conducted in Bandung regency. Based on preliminary observations, some adolescents in the research location showed different behaviors with adolescents in general. Some behaviors displayed by adolescents in the research location tend to behave in silence, lack of association, prefer to be alone, behave less actively socialize with the environment. Therefore, researchers interested in conducting research based on the behavior displayed adolescents caused by the adherence that builds between adolescents with working mother outside home.

The focus of research is how the attachment that is intertwined between adolescents with working mothers. To limit the scope of research, formulated the main issues of research that include; (1) how are the characteristics of informants ?; (2) how is the adolescent child's attachment to working mother ?; (3) how does a teenager relate to a working mother ?; (4) What is the intensity of meeting teenagers with working mothers?

\section{Method}

The research conducted in Bandung Regency Indonesia. This research used qualitative approach. Data resource consisted primary and secondary informant. Informants determination used purposive random sampling technique. The primary informant consisted eight persons including four adolescents and four working mothers. Besides the eight informants, the other data resource were informants' relative and neighbour who know the situation and condition of the main informant.

Data collection technique used in-depth interview, passive participation observation, and documentation study. In-depth interview, data collection was done by question and answer through face-to-face between researchers with informants based on interview guidelines. In this case, researcher and informants engage in social life for five months. The implementation of the interview was more free from the research structure. This means that it is not fixed on the instruments and interview guidelines that have been made. Before conducting in-depth interview, the researcher approached the initial approach and asked for informants' willingness to interview. After conducting in-depth interviews with key informants, the researcher continued with interviews with informant families and neighboring informants.

Data collection techniques were also done through passive participation observation. In this case the researcher visited the place of observation that is the residence of informants, but researcher did not get involved in the activities of adolescents in school and mother in work. Observation conducted by researcher were observing how attachments, relationships were intertwined and the intensity / frequency of time between adolescents with working mothers. In addition, researchers also observed the behavior that adolescents display from the attachment results that exist between adolescents with mothers. 
Data collection through documentation study is a complement to the use of observational data collection techniques and interviews. Through data collection techniques through documentation studies will make the results of data collection from interviews and observations to be more complete and valid. Documentation study conducted by the researchers is by conducting a study on the village profile, data and reports of informant activity at the research site.

Collected data and information were tested and checked for validity using inspection techniques based on a number of criteria. The technique of checking the validity of the data used in the research was the credibility test by means of extension of participation, increasing persistence, and triangulation. Triangulation used is triangulation of data sources, triangulation of data collection techniques, and time triangulation.

In processing and analyzing data, referring to qualitative data analysis according to Miles \& Huberman (1992) in Felix and Ivanovich (2003). Based on the description Miles and Huberman then in analyzing the data of this research conducted three lines of analysis that is; data reduction, data presentation and conclusions. Through data reduction, a selection process was undertaken, focusing attention on simplification, abstraction and transformation of coarse data arising from written records at the research site. This process was carried out continuously during the research, even before data was actually collected, as evidenced by the conceptual framework, research problem, and selected data collection approach. Activities undertaken in reducing data are through; summarizing data, coding, tracking themes, creating clusters; create partitions and write memos. Through the reduction of such data, sharpening, classifying, directing, removing unnecessary, and organizing data in such a way that final conclusions can be drawn.

After data reduction, then the next activity was presenting the data. The data that have been obtained then compiled into a collection of information so as to provide the possibility of drawing conclusions and taking action. The presentation of data is done in the form of narrative text from field notes and in the form of matrix, graph, or network and chart.

Further data analysis activities was drawing conclusions based on the results of the presentation of data that has been done. The conclusions were also still verified during the course of the research; rethink during writing, review of field notes and through review and exchange of ideas with peers and experts for their development.

\section{Research Result}

The results showed that the attachment generated by the four main informants both four adolescent informants and four informants working mothers have different attachments. The informant- 1 mother working with her child informant-1 adolescent has a very good bond. This is evidenced by the feelings, attitudes and behaviors displayed by the informants-1 teenagers to 1 nforman-1 working mothers look very good. 
Likewise, the informant's response-1 working mother looks good enough. Despite his busy work, a working informant-1 always cares for his child. The way informants The informants-1 working mothers are recognized can influence the behavior of the informant-1 adolescent.

Informants-2 mothers who work with their child informants- 2 adolescent have good bonds. However, the quality of the bond is what distinguishes it from informant-1. The results of the study found a difference of feelings between the informants- 2 adolescents with the informants- 2 working mothers. This is directed to the behavior that the two teenager's informants show when their mother is at work. This shows that between the two can not be said to establish a secure bond (secure attachment). The working informant-2 reveals that the relationship of meeting with the child begins to diminish. The informant- 2 working moms are aware of this because of her busy work. The ways in which the informants of the working mother also seem to impose the will of the child, ie not paying attention to the wishes of the child. This obviously will affect the child's development in the future.

Informants-3 mothers who work with their children's informants-3 adolescent have good bonds. However, the proximity time between the two is decreasing because the activities of children in school and residence and daily life of children who are not always together with the mother because of his mother's work at work.

The informants-4 mothers who work with their children's informants-4 adolescents show unfavorable bonds. The research finds attitudes and behaviors displayed by teenagers who seem indifferent. The working informants-4 acknowledged that the form of attention given when the child began to enter adolescence was diminished due to a condition, ie informants-4 teenagers who rarely are at home, making it difficult for informants- 4 mothers who work to do proximity to their teenage children.

The results of the research found that in general all adolescent informants had the same proximity relationship to their mother. But the various things that distinguish the relationship of proximity is the form of attention that the informant of the mother who works give to her child.

The form of attention given by the informant- 1 mothers who work against their child informants- 1 teenager is by always paying attention to each child's needs. The attention form of informants-2 mothers who work on their child-2 informants teenagers is by paying attention to the way children learn every day, and more attention to the quality of learning children. Unlike the case with the informants-3 working mothers and informants4 working mothers almost have the same in giving attention to their children is by contacting children when they are not with children. Physical contacts of adolescents and mothers who work informants-3 and informants 4 overall are not much different even the similarities of treatment done both. The results of the study found that basically the way informants of mothers who work in maintaining close relationships with children have 
almost the same way. All of this also depends on the child's response to this form of concern.

Based on the research result, the intensity that happened to the four main informants of teenagers and the four main informants of working mothers has different, that is referring to the frequency of meeting between adolescents with working mothers, the number of communications, as well as the openness of teenage informants with their working mother .

The results showed that the informant-1 working mother had the intensity of meeting with her child informant-1 adolescent was less. This happens because the busy informant- 1 working mother and also busy informant- 1 adolescent in daily activity that is school. Likewise with informants-2 mothers who work with their children informants- 2 teenagers where the intensity of meeting with their children is felt less because of busy moms and busy children working school. So the time togetherness of the informants-2 mothers who work with their children is less. Similarly, what was felt by the two informants of working mother (informant-3 and informant-4 working mothers) with two other child informants, ie informant-3 and informant-4 teenagers showed the intensity of the meeting felt very less because of busy working mother . Time togetherness with children is felt less not only because of busy informants in work but also the circumstances of his teenage children are rarely at home.

Based on the various problems perceived by all informants working mothers, busy mother in the work greatly affects the intensity of meetings between children and mothers. But unlike the informants-1 mothers who work with the informants-1 working children, although the informant-1 working mothers busy with work, the informant still maintain the relationship of proximity to the child in a way every day to take time to meet with their adolescents regularly after work.

\section{Discussion}

Every child has an attachment to parents, especially mothers. Because the role of parenting in the family in general cannot be separated from the role of a mother in maintaining, caring, caring, and raising children. The attachment is in line with the notion of stickiness in the opinion of Bowlby in Dariyo (2011), which states that attachment is a reciprocal emotional bond between a child and his caregiver due to the development of the quality of the previous relationship. The bond is beneficial for a child to gain a sense of security, protection and comfort from his mother.

Viewing from the aspects of adolescent attachment with mothers who work indicates that there is proximity between the child and his mother. The existence of this closeness is to give attention to the child in learning and health of his child. The mother's relationship with her child is close enough to be separated by the situation of the existence or distance of the school with the house. 
The proximity time of adolescents with working mothers is varied, either on holidays or at work, at work, and trying to find time to meet when school is scheduled only once a week. Although there is a distance and rarely meet, but the child's attachment with his mother is very close. That is, the intensity of the meet does not become an excuse to reduce the child's closeness with his mother. There are fears that children feel about their working mother. This is because her mother is often not at home to be with her. Children feel often abandoned. To keep communication with the child while always busy with work, working moms often use mobile phones to communicate with each other. There were teenagers who claim the effects of his mother is very busy with the work cause the meeting time is still lacking and the closeness and togetherness less well established.

Viewed from the aspect of an adolescent's feelings with a working mother indicates that despite her busy work, her mother is always worried about the activities her child is doing. Working mothers have the view that although their children are old enough there is a concern that the activities of their children violate the norms and values that exist in society. The same is also expressed by adolescent whose mothers work where they see that with the busyness of her mother worked feared not get affection and attention. Teenagers whose mothers work have the view that the activity of working mothers is feared to be anxious for their relationship.

Unlike the case with adolescents who since childhood was treated by housemaid. Adolescents who have been cared for by others or helpers are not worried when their mothers work. This kind of adolescent does not feel troubled when his mother is not around. Teenagers of this type also feel the work of his mother who worked. They understand that income generated from maternal employment can be utilized to meet their basic needs. Teenagers of this type often have the desire to complete education quickly and can help earn income to help the burden of his mother. This type of adolescent has a very good response and respect for their mother's busyness in the workplace. The kind of attention that teenagers show to their working moms is done by helping her mother take care of and fix the house.

Reviewing from the attitude and behavior of adolescent with working mothers was seen differences in attitudes shown children at the time of working and not working mother. This can be seen from the behavior of children who show an active attitude when his mother was at work while if her mother does not exist, she showed a quiet attitude.

The proximity of adolescents with their working mother was demonstrated by maintaining communication over the phone. Although their mothers are busy with a variety of jobs but there is an effort to keep in touch to keep an eye on phone communications. Physical contact of a teenager with a working mother is a form of concern or affection. This is also done by the child as a form or form of respect for the child's mother through kissing hands. Giving a great opportunity to the child to tell a story, and after that responded by her mother is one form of attention of mothers who work against their children. The goal is to give the child a chance to be able to address 
his problem or complaint. The form of attention is also done by teenagers to his mother who works by helping her mother at the time of illness. In this context, there is mutual concern.

The frequency of proximity of children with working mothers decreases when both were engaged in activities. If adolescents were doing school activities and their mothers were working then the frequency of proximity decreases. But when the day off then the relationship of adolescents with their working mother became closely back. The results showed that adolescents often want more intensive communication frequency with their mothers who work either done directly (face to face) or through communication tools over the phone. However, adolescents realize that it will interfere with her mother's work activities.

The decrease in the frequency of the child's proximity to the mother is also influenced by the activity of a teenager who rarely returns because he or she is with his friends or is doing an activity away from his home on the grounds of the school. This situation causes teenagers lack communication with their mothers. However, to overcome these problems, both adolescents and working mothers try to be frank and communicate with regard to the activities undertaken by both. This brings benefits to the relationship of both so easily solve the problems faced by his son.

Based on the results of research conducted by researchers about adolescent with working mothers, the results obtained from four aspects of research that the attachment resulting from the relationship between mother and adolescent children can be said less than optimal, so that required intervention program. The child experienced an inevitable process of growth and development because it is a natural process that occurs with age. The process of growth and development, can not be separated from the various roles of parents in helping the child's growth function. Looking at the process of growing children, the more children grow, the problems faced by children will be growing. The child's issues are back on how the parent's role and way of giving attention, nurturing and learning to the child at every stage of his growth.

The role of parents, especially mothers in raising and educating children is very important for the survival of children in the future. Moreover, children begin to enter adolescence, where adolescents are a transitional period into adulthood or in adult development. Parents, especially mothers, are seen as having strong strength and influence over their children's care pattern properly and correctly.

Problems and needs felt by adolescents, especially whose mothers work are: (1) the mother has limited understanding and awareness in educating and nurturing her children; (2) the mother instill an authoritarian pattern in which the mother dominates over the needs and wants of the child regardless of the needs and desires of the child, especially in his teenage child.

Berdasarkan hal tersebut bahwa ibu kurang menyadari apa yang pada umumnya mereka lakukan selama ini terhadap anak remajanya dapat menjadikan dampak yang negatif. Adapun dampak positif dari pola pengasuhan yang saat ini ibu lakukan tersebut adalah memang pada dasarnya akan membuat anak menjadi lebih mandiri, dan 
bertanggung jawab dalam setiap permasalahan yang dirasakan oleh anak remajanya, tetapi tanpa disadari bahwa anak bisa saja mengalami dampak sebaliknya yaitu anakakan merasakan takut, anak merasa minder bahkan bisa saja anak menjadi kurang percaya diri.

Thus, the pattern of mother care that works against adolescents is necessary to increase the understanding of care for mothers. This is what mothers do for their adolescents because mothers generally instill the values and teachings they once had from their parents. One of the informants of the mother never realized that the pattern of parenting is only concerned with the wishes of the mother and always ruled to the child who had been one of the informants apply to her child is no longer in accordance with the development of the current era.

Lack of knowledge of mothers in providing a good and effective parenting pattern for adolescents, it is necessary to provide knowledge and understanding of mothers, especially working mothers in order to apply good and correct parenting patterns and effective against their children. Mothers who have difficulty in dealing with various problems felt by children, also experience difficulties when having to share the time between busyness in work, and also attention to these children, so the need of education of understanding specifically for mother, so that mother able to educate, raising his children.

The need for education and understanding of mothers who work on the care of their children is important. Because in the hands of parents a quality of future generations is determined. Parents in this case means the role of a mother. The more mothers who understand, understand, and succeed in educating and nurturing their children well, then the quality of society and future generations will also be better.

Interventions of social work in handling problems experienced by mothers in the family is the awareness of mothers who work through social counseling about the pattern of child care and the formation of the Child Care Mother group. The general goal of solving this problem is to provide awareness for mothers who work in providing good parenting to children. In particular, this problem-solving process is aimed at improving the understanding and role of working mothers in their role in children. In addition, aimed at the formation of Community Working Team (TKM) care for children. The activities are divided into two sessions which will be explained as follows.

\section{Social Counseling}

Social counseling is a process of Communication, Information and Education (IEC) organized in a planned, integrated, and sustainable, to form knowledge of community insight about the development of social welfare and social aspects of the activities of other sectors. The goal is to create an attitude of consciousness to take the initiative and role in social development.

Social counseling activities in this program aimed to improve knowledge and understanding of mothers who work in providing care to children. It is expected that 
with the social counseling, the community, especially working mothers, has knowledge and understanding and can increase their role in overcoming the problems of children. The material to be delivered in this counseling activity is about good parenting material, convention of children rights, and policy about children.

The formation of a child care mother group

After the community especially working mothers are given knowledge and understanding through social counseling activities, then the next activity is the formation of a group of child care mothers. The purpose of this group of child care mothers is as a forum for mothers so that the mothers can share or share problems faced about their children. This child care mothers group works with relevant stakeholders. Activities undertaken by this group of child care mothers is like a meeting wherein sharing experiences or sharing about problems in children, the needs of children, and future goals that will be able to work with social workers concerned to continue to develop activities that work especially to the mothers who have been identified that the mother works and also have adolescents and targets that are expected to represent the implementation of these activities. Implementation of the mother awareness program that works on the pattern of care of his teenage children requires cooperation from various parties who are experts in the field of children and family.

\section{Conlcusion}

The results of this research are very important for working mothers to pay more attention to the importance of adhesions between adolescents with mothers. Ank teenager has its own problems in the life of logging his life. On the other hand, in carrying out his life activities, adolescents need others, especially those closest to him to share and find alternatives in solving the problems of development of his life. According to the results of research, teenagers need more mother in pouring and discussing in handling problem faced at the time of its life.

The results is also very important for adolescents in handling problems in the life of pekermbangan life. For teenagers, problems in the development of life can be overcome through the process of communication with the person closest to him that is the mother. On the other hand the condition of working mothers cause children to worry can disrupt his work when adolescents will communicate and make relationships. Therefore, when both are off then the time can be used by both (adolescent and working mother) to increase the intensity of attachment.

The intensity of attachment that exists between adolescents and working mothers has differences between one family and another. Various factors that may affect the difference in intensity of attachment between adolescent and working mother include; history of child care patterns using caregivers or domestic helpers; awareness and understanding both (adolescent and working mother) on their respective activities; and 
an alternative effort made both to deal with problems that impede communication. However, both teenagers and working mothers have similar feelings of concern about their circumstances.Third children feel worried when their working moms do not give the maximum attention. On the other hand, working mothers are worried about their children's activities in outside the home breaking the value, and the norms of society.

Based on the aspect of the closeness relationship that the closeness relationship between adolescent and working mother in general was good. In general, although the mother of the adolescent works, but the working mother is always concerned about the development and activities performed by his teenage child. Working mothers will try to balance between the responsibility of Java as a mother with responsibility as an employee. Even when the child has problems in the development of his life, working mothers will prioritize their teenagers in comparison with their work. It is realized by the mother who works that her son's future is more important than her work. However, working moms will try to balance between career as an employee by taking care of her teenage child.

The intensity of meetings between adolescents and working mothers has problems because both were more active outside the home. Working moms were busy with her job. On the other hand, adolescents are busy with activities at school and hanging out with their peers. However, working mothers try to always pay attention to the problems facing adolescent children. The working mom will try to spend her time to increase the intensity of meeting with her teenage child when she was away from work. Working moms realize that busyness in working with conditions that are less attention to the needs in child development will affect the behavior displayed by children, especially children in adolescence.

The child experienced an inevitable process of growth and development because it was a natural process that occurs with age. The process of growth and development, cannot be separated from the various roles of parents in helping the child's growth function. Looking at the process of growing children, the more children grow, the problems faced by children will be growing. The child's issues were back on how the parent's role and way of giving attention, nurturing and learning to the child at every stage of his growth.

The role of parents, especially mothers in raising and educating children is very important for the survival of children in the future. Moreover, children begin to enter adolescence, where adolescents are a transitional period into adulthood or in adult development. Parents, especially mothers, are seen as having strong strength and influence over their children's care pattern properly and correctly. 
Indonesian Journal of Social Work (IJSW)

Vol.1 Issues.1, August 2017 page 1 - 133

Bandung College of Social Welfare

\section{References}

Dariyo, A. (2011). Psikologi perkembangan (anak tiga tahun pertama). Bandung: Refika Aditama

Desmita (2007). Psikologi perkembangan. Bandung : Refika Aditama

Goldberg, S. (2000). Attachment theory : social, developmental and clinical perspectives. New York : The Analytic Press http://library.usu.ac.id/download/fk/ psikologi-eka\%20ervika_pdf, acces; 1/12/2017.

Hurlock, E. B. (1980). Psikologi perkembangan (edisi kelima). Jakarta: Erlangga

Kartini Kartono (2005). Patologi sosial 2 (kenakalan remaja) cetakan keenam. Jakarta : PT Raja Grafindo Persada

Monks, F. J. (2006). Psikologi perkembangan. Yogyakarta: UGM Press.

Netting, F. Ellen., Kettner \& McMurtry (2001). Social work macro pratice. United State of America (New York) : Pearson

Santrock, J.W. (2007). Remaja (edisi 11 jilid 1). Jakarta : Erlangga

Santrock, J.W. (2010). Remaja (edisi 11 jilid 2). Jakarta : Erlangga

Sri Lestari (2012). Psikologi keluarga (penanaman nilai dan penanganan konflik dalam keluarga). Jakarta : Kencana Prenada Media Grup

Sutcliffe, J., (2002). Baby bonding, membentuk ikatan batin dengan bayi. Jakarta: Taramedia \& Restu Agung. https://www.google.co.id/?gws_ rd=cr,ssl\&ei=iSERVIaZI8yGuATjhoJI\#q=aspek-aspek+kelekatan, $\quad$ acces $2 / 12 / 2016$

Weiten, W. (2011). Psychology: themes and variations 8th edition. Las Vegas: Wadsworthhttp://kiatmembangunkelekatandengananak.rumah belajarpsikologi.com 